\title{
SYMPOSIUM OF THE WHOLE
}





\title{
SYMPOSIUM OF THE WHOLE
}

A Range of Discourse Toward an Ethnopoetics

\section{Edited with Commentaries by}

\author{
Jerome Rothenberg \\ \& \\ Diane Rothenberg
}


UNIVERSITY OF CALIFORNIA PRESS

Berkeley and Los Angeles, California

UNIVERSITY OF CALIFORNIA PRESS, LTD.

London, England

COPYRIGHT (C) 1983 BY THE REGENTS OF THE UNIVERSITY OF CALIFORNIA

\section{Library of Congress Cataloging in Publication Data}

Main entry under title:

Symposium of the whole.

Bibliography: p. 485

1. Poetry-History and criticism-Addresses, essays,

lectures. 2. Literature and society-Addresses, essays,

lectures. 3. Religion and poetry-Addresses, essays,

lectures. I. Rothenberg, Jerome, 1931-

II. Rothenberg, Diane.

PN1081.S9 809.1 82-40092

ISBN 978-0-520-29311-3 (pbk: alk. paper)

PRINTED IN THE UNITED STATES OF AMERICA

10987654321

212019181716 
For Michel Benamou (1929-1978) 
